\title{
Studi Jamur Cryptococcus Neoformans Penyebab Kriptokokosis pada Kotoran Burung, Tanah, dan Udara di Pasar Burung Lingkungan Sindu dengan Media Potato Dextrose Agar (PDA)
}

\author{
Siti Nabila Mustiani*, Yunan Jiwintarum, Yudha Anggit Jiwantoro \\ Jurusan Analis Kesehatan, Poltekkes Kemenkes Mataram, Indonesia \\ *Email korespondensi : nabilamus9@ gmail.com
}

\begin{abstract}
Abstrak
Cryptococcus neoformans adalah jamur patogen oportunistik penyebab kriptokokosis, yaitu mikosis yang berpotensi mematikan pada manusia. Jamur ini banyak terdapat pada lingkungan yang tercemar kotoran burung seperti pasar burung. Salah satu pasar burung yang keadaan lingkungannya mendukung untuk pertumbuhan Cryptococcus neoformans adalah pasar burung Lingkungan Sindu, namun belum pernah diteliti tentang adanya jamur Cryptococcus neoformans di lingkungan tersebut. Penelitian ini bertujuan untuk mengetahui studi jamur Cryptococcus neoformans penyebab kriptokokosis pada kotoran burung, tanah, dan udara di pasar burung Lingkungan Sindu dengan media Potato Dextrose Agar (PDA). Penelitian ini menggunakan metode observasional deskriptif dengan total 12 sampel yang diambil dari 4 area di pasar burung Lingkungan Sindu. Data yang dikumpulkan berupa hasil identifikasi makroskopis dan mikroskopis koloni yang tumbuh pada media PDA. Hasil identifikasi menunjukkan bahwa Cryptococcus neoformans terdapat pada 2 sampel dari 4 sampel kotoran burung, 1 sampel dari 4 sampel udara, dan tidak terdapat pada sampel tanah. Hal ini menunjukkan bahwa jamur Cryptococcus neoformans ditemukan paling banyak pada sampel kotoran burung yaitu $50 \%$, kemudian pada sampel udara yaitu $25 \%$, sementara pada sampel tanah tidak ditemukan jamur Cryptococcus neoformans (0\%).
\end{abstract}

Kata kunci: Cryptococcus Neoformans, Kriptokokosis, Potato Dextrose Agar

\begin{abstract}
Cryptococcus neoformans is an opportunistic yeast pathogen that causes cryptococcosis, a potentially lethal mycosis in human. This fungi is widely found in places that contaminated by bird droppings such as bird market. Bird market in Sindu region has environmental conditions that can support the growth of Cryptococcus neoformans, but the habitat of this yeast in Sindu Bird Market has not been yet studied. This study aims to determine the study of Cryptococcus neoformans that causes Cryptococcosis in bird dropping, soil, and air in the Sindu Bird Market with Potato Dextrose Agar (PDA) growth media. The method used in this study is descriptive observational method with total of 12 samples taken from 4 areas in Sindu Bird Market. Data collected from the results of macroscopic and microscopic identification of colonies that grow on PDA. The results showed that Cryptococcus neoformans were found in 2 samples from 4 samples of bird droppings, 1 sample from 4 air samples, and did not found in soil samples. This means Cryptococcus neoformans was found the most in bird droppings which was $\mathbf{5 0 \%}$ and found in air samples which was $\mathbf{2 5 \%}$, while in soil samples there was no Cryptococcus neoformans found $(0 \%)$.
\end{abstract}

Keywords: Cryptococcus Neoformans, Cryptococcosis, Potato Dextrose Agar

\section{PENDAHULUAN}

Kriptokokosis merupakan infeksi jamur oportunistik yang banyak menyebabkan kematian pada pasien immunocompromised (imunitas lemah) dengan insidensi di seluruh dunia mencapai $2-72 \%$. Infeksi ini berupa infeksi sistemik atau merata dan melibatkan aliran darah serta berbagai macam organ.
Munculan klinis yang paling sering adalah meningitis dan meningoensefalitis. Spesies utama yang menyebabkan kriptokokosis adalah Cryptococcus neoformans (Adawiyah \& Syam, 2014).

Cryptococcus neoformans adalah jamur uniseluler yang tersebar kosmopolit, habitatnya adalah pada lingkungan yang tercemar kotoran 
burung terutama burung merpati. Jamur ini bersifat dimorfik yaitu berbentuk ragi saat di dalam tubuh manusia dan pada media perbenihan, serta berbentuk kapang saat tumbuh di alam. Cryptococcus neoformans di alam bebas memproduksi basidiospora di permukaan tanah (soil) yang sedikit terkena sinar matahari dan terbawa bersama debu melalui udara, sehingga dapat menjadi sumber infeksi apabila terinhalasi oleh manusia (Adawiyah \& Wahyuningsih, 2012; Spickler, 2013).

Kasus kriptokokosis tertinggi ditemukan di Sub Sahara-Afrika yaitu sebanyak 720.000 per tahun, kemudian di Asia Selatan dan Asia Tenggara mencapai 120.000 kasus per tahun. Di Indonesia, Departemen Parasitologi FKUI mencatat insidensi meningitis yang disebabkan oleh Cryptococcus neoformans mengalami peningkatan tajam sejak pandemi AIDS tahun 2004 yaitu sebesar 21,9\%. Rumah Sakit Persahabatan Jakarta pada tahun 2006 mendiagnosis dua kasus pasien dengan kriptokokosis paru. Di Bandung, Akhmad tahun 2008 melaporkan 30\% pasien AIDS dengan gangguan sistem saraf pusat terbukti menderita meningitis Cryptococcus. Di Padang, kasus penderita AIDS dengan kriptokokosis yang dilaporkan adalah ditemukannya pertama kali satu kasus di Laboratorium Patologi Anatomi Fakultas Kedokteran Universitas Andalas tahun 2007 (Suta, 2006; Efrida, 2012).

Laporan kasus kriptokokosis dan informasi tentang kriptokokosis di Indonesia masih rendah dan belum menggambarkan jumlah kejadian yang sebenarnya di lapangan. Hal ini dapat disebabkan karena penderita kriptokokosis jarang terdiagnosis, sehingga upaya pencegahan terhadap kejadian kriptokokosis juga belum dilakukan (Japardi, 2002).

Upaya peningkatan diagnosis dan pencegahan kriptokokosis dapat dilakukan salah satunya dengan melakukan studi tentang keberadaan jamur Cryptococcus neoformans pada lingkungan yang berpotensi sebagai habitat hidupnya dengan bantuan media pertumbuhan dasar jamur yang dapat menyediakan nutrisi bagi pertumbuhan Cryptococcus neoformans, seperti media Potato Dextrose Agar (PDA).

Penelitian terdahulu di beberapa Negara di Asia berhasil mengisolasi jamur
Cryptococcus neoformans dari berbagai sumber penyebaran kriptokokosis seperti kotoran burung merpati kering, kotoran burung merpati basah, dan bunga eukaliptus dengan menggunakan media PDA dan SDA (Sriburee et. al., 2004; Wu et. al., 2012). Bahkan Cryptococcus neoformans pernah diisolasi dari udara dalam kandang burung di sebuah kebun binatang di Colombia. Di pulau Lombok, tepatnya di Kuta dan Gili, Sjamsulridzal dkk. (2010) juga berhasil mengisolasi Cryptococcus $s p$. dari berbagai sampel seperti tanah, sampah, bunga, serbuk sari, dedaunan, dan serangga.

Pasar burung di lingkungan Sindu, Kecamatan Cakranegara, merupakan pusat penjualan burung yang terletak di Kota Mataram. Sangkar burung yang diletakkan secara berderet dan menumpuk di sepanjang lokasi menyebabkan penumpukan kotoran burung yang mencemari lingkungan sekitar. Keadaan pasar burung yang memiliki kelembaban tinggi, kurangnya sinar matahari, dan kandungan nitrogen yang tinggi dari cemaran kotoran burung merupakan keadaan yang cocok untuk mendukung pertumbuhan Cryptococcus neoformans (Adawiyah \& Wahyuningsih, 2012).

Data mengenai keberadaan jamur Cryptococcus neoformans yang menjadi penyebab utama kriptokokosis di lingkungan yang tercemar kotoran burung seperti pasar burung di lingkungan Sindu belum ada. Oleh sebab itu, perlu dilakukan penelitian mengenai studi jamur Cryptococcus neoformans penyebab infeksi kriptokokosis di pasar burung lingkungan Sindu dengan memanfaatkan media Potato Dextrose Agar (PDA) sebagai media pertumbuhan.

\section{METODE}

Penelitian ini bersifat Observasional Deskriptif, yaitu peneliti mengamati secara langsung objek yang diteliti, kemudian digambarkan secara deskriptif untuk mengetahui ada atau tidaknya Cryptococcus neoformans pada sampel yang diambil dari pasar burung lingkungan Sindu.

Teknik pengambilan sampel pada penelitian ini adalah Non Random Sampling yaitu dengan Purposive Sampling, merupakan pengambilan sampel berdasarkan kriteria yang dibuat oleh peneliti sendiri (Notoatmodjo, 2012). 
Adapun kriteria sampel yang digunakan dalam penelitian ini adalah habitat hidup Cryptococcus neoformans yang dapat ditemukan di pasar burung lingkungan Sindu yaitu berupa kotoran burung yang sudah kering, tanah di sekitar kandang burung yang telah terkontaminasi kotoran burung, dan udara di dekat kandang burung yang diambil dari 4 titik.

Data yang diperoleh berupa ada atau tidaknya pertumbuhan Cryptococcus neoformans pada media pertumbuhan PDA melalui pengamatan makroskopis dan mikroskopis.

\section{HASIL}

Tabel 1. Hasil Identifikasi Koloni yang dimurnikan pada media PDA secara makroskopis dan mikroskopis

\begin{tabular}{|c|c|c|c|c|c|c|}
\hline \multirow[b]{2}{*}{$\begin{array}{c}\text { No } \\
\text {. }\end{array}$} & \multirow[b]{2}{*}{$\begin{array}{c}\text { Jenis } \\
\text { Samp } \\
\text { el }\end{array}$} & \multirow[b]{2}{*}{$\begin{array}{c}\text { Kode } \\
\text { Samp } \\
\text { el }\end{array}$} & \multirow{2}{*}{$\begin{array}{c}\text { Makrosko } \\
\text { pis koloni } \\
\text { pada } \\
\text { media } \\
\text { PDA }\end{array}$} & \multicolumn{2}{|c|}{ Mikroskopis } & \multirow[b]{2}{*}{ Hasil } \\
\hline & & & & $\begin{array}{l}\text { Pewarna } \\
\text { an Gram }\end{array}$ & $\begin{array}{c}\text { Pewarna } \\
\text { an } \\
\text { Kapsul }\end{array}$ & \\
\hline \multirow{2}{*}{1.} & \multirow{2}{*}{$\begin{array}{l}\text { Kotor } \\
\text { an } \\
\text { Burun } \\
\mathrm{g}\end{array}$} & $\mathrm{K} 2$ & $\begin{array}{l}\text { Ragi, bulat, } \\
\text { krem, } \\
\text { mukoid }\end{array}$ & Gram (+) & + & $\begin{array}{l}\text { C. } \\
\text { neoforma } \\
\text { ns }\end{array}$ \\
\hline & & K4 & $\begin{array}{l}\text { Ragi, bulat, } \\
\text { krem, } \\
\text { mukoid }\end{array}$ & Gram (+) & + & $\begin{array}{l}\text { C. } \\
\text { neoforma } \\
\text { ns }\end{array}$ \\
\hline 2. & Tanah & $\mathrm{T} 3$ & $\begin{array}{l}\text { Ragi, bulat, } \\
\text { krem, } \\
\text { mukoid }\end{array}$ & Gram (+) & - & $\begin{array}{l}\text { Bukan } \\
\text { C. } \\
\text { neoforma } \\
\text { ns }\end{array}$ \\
\hline \multirow[t]{2}{*}{3.} & \multirow[t]{2}{*}{ Udara } & U1 & $\begin{array}{l}\text { Ragi, bulat, } \\
\text { krem, } \\
\text { mukoid }\end{array}$ & Gram (+) & - & $\begin{array}{l}\text { Bukan } \\
C . \\
\text { neoforma } \\
n s\end{array}$ \\
\hline & & $\mathrm{U} 2$ & $\begin{array}{l}\text { Ragi, bulat, } \\
\text { krem, } \\
\text { mukoid }\end{array}$ & Gram (+) & + & $\begin{array}{l}C . \\
\text { neoforma } \\
n s\end{array}$ \\
\hline
\end{tabular}

Tabel 1 menunjukkan bahwa semua koloni yang dimurnikan ke media PDA dengan metode streak 4 kuadran menunjukkan hasil Gram positif, sementara pada pengecatan kapsul, koloni yang menunjukkan hasil negative kapsul adalah koloni yang tumbuh dari sampel tanah di titik 3 (T3) dan sampel udara di titik 1 (U1). Sedangkan hasil positif kapsul ditunjukkan oleh koloni yang tumbuh dari sampel kotoran burung di titik 2 dan titik 4 (K2 dan K4), serta sampel udara di titik 2 (U2).

Hal ini menunjukkan bahwa jamur $C$. neoformans paling banyak ditemukan pada sampel kotoran burung yaitu pada 2 sampel dari 4 sampel kotoran burung (50\%), kemudian pada sampel udara yaitu 1 sampel dari 4 sampel udara (25\%), serta tidak ditemukan pada 4 sampel tanah $(0 \%)$.

Hasil pengamatan koloni secara makroskopis dan mikroskopis dapat dilihat pada gambar 1 .

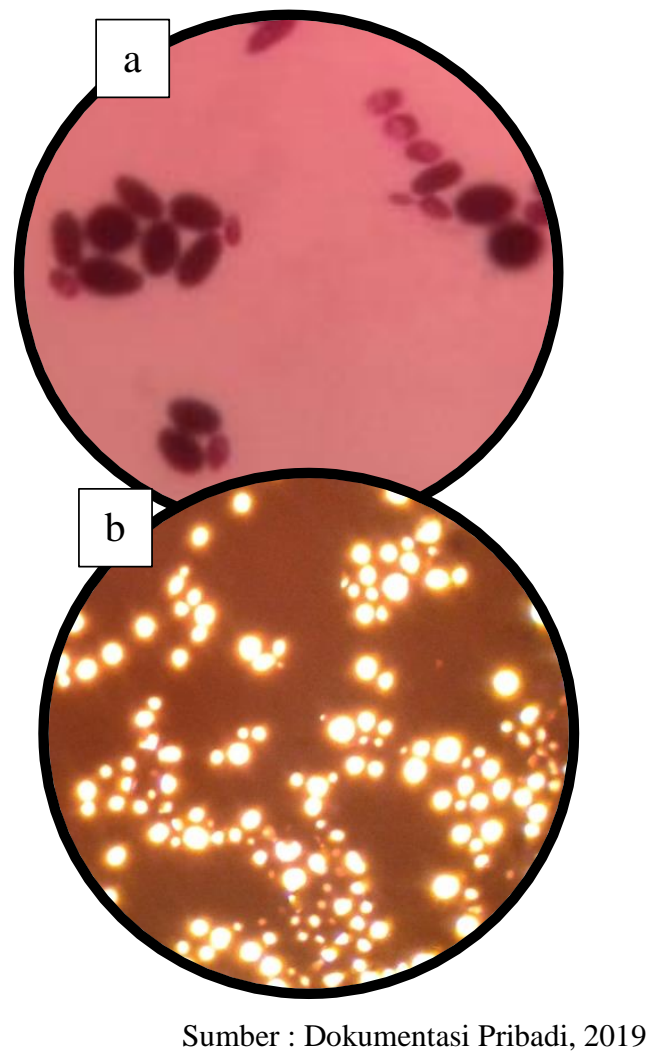

Gambar 1. Hasil Pengamatan Koloni Secara Mikroskopis, (a) Pewarnaan Gram, (b) Pewarnaan Kapsul.

\section{PEMBAHASAN}

Penelitian ini dilakukan untuk mengetahui studi tentang jamur Cryptococcus neoformans penyebab kriptokokosis pada kotoran burung, tanah dan udara di pasar burung Lingkungan Sindu dengan media Potato Dextrose Agar (PDA). Sampel yang dipakai pada penelitian ini yaitu kotoran burung, tanah, dan udara, karena habitat alami Cryptococcus neoformans adalah pada kotoran burung terutama burung merpati. Menurut Spickler (2013), satu gram kotoran merpati dapat mengandung lebih dari $10^{6}$ sel Cryptococcus neoformans. Selain pada kotoran burung merpati, Cryptococcus neoformans juga dapat ditemukan pada tanah. Basidiospora dari Cryptococcus neoformans yang menyebabkan kriptokokosis dihasilkan di permukaan tanah (soil). Sementara debu di udara dapat membawa spora Cryptococcus neoformans sehingga dapat menyebar pada lingkungan. 
Ketiga jenis sampel tersebut diambil pada 4 titik yang dipilih untuk mewakili keadaan keseluruhan di pasar burung tersebut, yaitu titik 1 adalah area di dekat pintu masuk yang merupakan area terpadat, titik 2 adalah area pasar yang mempunyai atap sehingga area tersebut tidak terkena sinar matahari secara langsung, titik 3 adalah area pasar yang tidak mempunyai atap sehingga terkena sinar matahari secara langsung, dan titik 4 adalah area pasar yang terletak paling belakang dan banyak penumpukan kotoran burung yang sudah kering.

Cryptococcus neoformans mempunyai sifat termotoleran yaitu dapat tumbuh pada suhu $37^{\circ} \mathrm{C}$, sehingga inkubasi dilakukan pada suhu tersebut agar spesies Cryptococcus lain tidak tumbuh dan menghalangi pertumbuhan Cryptococcus neoformans. Koloni Cryptococcus neoformans mempunyai ciri-ciri yaitu berjenis ragi (yeast), berbentuk bulat, berwarna putih krem, cembung, pinggiran rata, dan mukoid (Brooks, 2012; Kidd et. al., 2016). Pengamatan koloni setelah diinkubasi selama 3x24 jam menunjukkan pertumbuhan koloni yang menyerupai koloni Cryptococcus neoformans. Koloni tersebut berasal dari isolat kotoran burung yang diambil dari titik 2 (K2) dan titik 4 (K4), isolat tanah dari titik 3 (T3), dan isolat udara dari titik 1 (U1) dan titik 2 (U2).

Koloni ragi yang dicurigai sebagai Cryptococcus neoformans dimurnikan kembali pada media PDA yang baru untuk menghindari media terlalu padat dan pertumbuhan Cryptococcus neoformans tidak terhalangi oleh koloni jamur lain. Kemudian diamati secara mikroskopis dengan pewarnaan Gram untuk melihat sifat dan morfologinya dan pewarnaan kapsul dengan tinta india untuk melihat keberadaan kapsul yang merupakan ciri Cryptococcus neoformans.

Berdasarkan pengecatan Gram yang dilakukan, didapatkan sel jamur berbentuk sel ragi oval dan mempunyai budding sebagai bentuk reproduksi aseksualnya, dan berwarna ungu yang menunjukkan sifat Gram positif yaitu mempertahankan warna Kristal violet. Diketahui sel ragi Cryptococcus neoformans mempunyai sifat Gram positif, berbentuk bulat atau oval dan mempunyai simpai (kapsul) dengan diameter sel ragi berkisar antara 5-10 $\mu \mathrm{m}$ (Kidd et. al., 2016).
Berdasarkan pengecatan kapsul dengan tinta india, didapatkan hasil positif kapsul pada sampel K2, K4, dan U2. Positif kapsul ditandai dengan adanya daerah bening di sekeliling sel jamur yang tidak terwarnai oleh tinta india, daerah bening tersebut merupakan kapsul polisakarida yang mengelilingi sel jamur. Kapsul Cryptococcus neoformans terdiri atas beberapa komponen yaitu polisakarida (95\%), enzim dan protein. Kapsul ini merupakan faktor virulensi utama dalam pertahanan hidup Cryptococcus neoformans, lebar kapsul bervariasi tergantung kondisi lingkungan, kadar $\mathrm{CO}_{2}$, rendahnya kadar zat besi, dan faktor nutrisi. Ukuran kapsul akan melebar pada media dengan kadar glukosa rendah dan sebaliknya akan mengecil pada media yang kaya glukosa seperti Potato Dekstrose Agar (PDA) (Adawiyah \& Wahyuningsih, 2012).

Berdasarkan hasil penelitian yang telah dilakukan, Cryptococcus neoformans paling banyak ditemukan pada sampel kotoran burung yaitu positif pada 2 sampel dari total 4 sampel (50\%), kemudian pada sampel udara yaitu positif pada 1 sampel dari total 4 sampel (25\%), sementara pada sampel tanah tidak ditemukan Cryptococcus neoformans dari total 4 sampel yang diteliti. Menurut titik pengambilan sampel, jamur Cryptococcus neoformans teridentifikasi dari dua titik yaitu titik 2 dan titik 4, sementara pada titik 1 dan titik 3 tidak didapatkan hasil positif.

Hasil penelitian ini sejalan dengan penelitian Ellabib et. al. (2016) dan Wu et. al. (2012) yang berhasil mengidentifikasi Cryptococcus neoformans dari isolat kotoran burung, serta sejalan dengan keadaan lingkungan pasar burung yang menyediakan berbagai faktor pendukung pertumbuhan jamur Cryptococcus neoformans sepert intensitas sinar matahari yang kurang, kelembaban tinggi yang dapat meningkatkan daya tahan dan proliferasi Cryptococcus neoformans, dan keberadaan beberapa komponen dalam kotoran burung yang berperan dalam pertumbuhan Cryptococcus neoformans antara lain kreatinin sebagai sumber nitrogen dan asam urat serta purin yang digunakan untuk asimilasi jamur (Adawiyah \& Wahyuningsih, 2012; Spickler, 2013).

Pertumbuhan Cryptococcus neoformans dalam media perbenihan maupun di dalam tubuh manusia terlihat dalam bentuk ragi, 
namun saat tumbuh di alam jamur ini berbentuk kapang dan memproduksi basidiospora di permukaan tanah (soil) dan terbawa bersama debu melalui udara. Apabila sel ragi kecil atau basidiospora tersebut terhirup oleh manusia maka dapat memicu terjadinya kolonisasi pada saluran nafas dan kemudian diikuti oleh infeksi terutama pada individu yang mempunyai imunitas lemah. Kemudian menyebar secara hematogen sampai ke sistem saraf pusat dan menyebabkan meningitis yang dapat menyebabkan kematian (Kirk, et. al., 2008; Efrida, 2012; Febrylla et. al., 2015).

\section{KETERBATASAN PENELITIAN}

Pengambilan sampel penelitian ini hanya dalam 1 waktu, sesuai dengan metode yang digunakan yaitu Observasional Deskriptif kurang sesuai.

\section{SIMPULAN}

Kesimpulan dari penelitian ini adalah Cryptococcus neoformans teridentifikasi pada sampel kotoran burung sebanyak 2 dari 4 sampel, pada sampel udara sebanyak 1 dari 4 sampel dan tidak teridentifikasi pada 4 sampel tanah. Cryptococcus neoformans ditemukan paling banyak pada sampel kotoran burung yaitu $50 \%$, kemudian sampel udara yaitu $25 \%$, sementara pada sampel tanah tidak ditemukan jamur Cryptococcus neoformans (0\%).

\section{SARAN}

Meningkatkan penelitian tentang Cryptococcus neoformans sebagai bentuk antisipasi dampak pada manusia.

\section{UCAPAN TERIMA KASIH}

Terima kasih kepada pembimbing dan seluruh dosen di jurusan Analis Kesehatan yang telah banyak membantu dalam penyelesaian penelitian ini.

\section{DAFTAR PUSTAKA}

Adawiyah, R., dan Syam, R. (2014). Deteksi Antigen pada Kriptokokosis. Antibiotik Topikal Sebagai Alternatif Terapi Ulkus, 2(2), 127-132.

Adawiyah, R., dan Wahyuningsih, R. (2012). Kriptokokosis: Epidemiologi, Manifestasi Klinis dan Diagnosis. Majalah Kedokteran FK UKI, 28(3), 133-143.
Brooks, G. F. (2012). Mikrobiologi Kedokteran Jawetz, Melnick, \& Adelberg. (A. W. Nugroho \& A. Adityaputri, Eds.) (25th ed.). Jakarta: EGC.

Efrida, D. (2012). Kriptokokal meningitis: Aspek klinis dan diagnosis laboratorium. Jurnal Kesehatan Andalas, 1(1), 39-44.

Ellabib, M. S., Aboshkiwa, M. A., Husien, W. M., D'Amicis, R., \& Cogliati, M. (2016). Isolation, Identification and Molecular Typing of Cryptococcus neoformans from Pigeon Droppings and Other Environmental Sources in Tripoli, Libya. Mycopathologia, 181(7-8), pp. 603-608. doi: 10.1007/s11046-016-9996-4.

Febrylla, S., Natalia, D., dan Susanti, W. E. (2015). Identifikasi Kriptokokosis dengan Metode Lateral Flow Assay (LFA) pada Pasien HIV/AIDS di Klinik Melati RSUD dr. Soedarso Pontianak Periode September-Desember 2014.

Japardi, I. (2002). Infeksi Jamur pada Susunan Saraf Pusat, 1-4.

Kidd, S., Halliday, C., Alexiou, H., dan Ellis, D. (2016). Descriptions of Medical Fungi. Adelaide: Newstyle Printing.

Kirk, P. M., Cannon, P. F., Minter, D. W., dan Stalpers, J. A. (2008). Ainsworth \& Bisby's Dictionary of the Fungi. (10th ed). Wallingford: Cab International.

Notoatmodjo, S. (2012). Metodologi Penelitian Kesehatan. Jakarta: Rineka Cipta.

Sjamsuridzal, W., Oetari, A., Kanti, A., Saraswati, R., Nakashima, C., Widyastuti, Y., \& Katsuhiko, A. (2010). Ecological and Taxonomical Prespective of Yeast in Indonesia. Microbiology Indonesia, 4(2), 60-68.

Spickler, A. R. (2013). Cryptococcosis. Retrieved from http://www.cfsph.iastate.edu/DiseaseInfo/f actsheets.php

Sriburee, P., Khayhan, S., Khamwan, C., Panjaisee, S., \& Tharavichitkul, P. (2004). Serotype and PCR-fingerprints of Clinical 
and Environmental isolates of Cryptococcus neoformans in Chiang Mai, Thailand. Mycopathologia, 158(1), 25-31. https://doi.org/10.1023/B:MYCO.0000038 $\underline{435.14281 . \mathrm{f} 4}$

Suta, I. B. (2006). Diagnosis dan Penatalaksanaan Mikosis Paru. di dalam Workshop on Pneumonia, Deal the Challenge-Improve the Outcome. I. B. N. Rai, dan I. G. N. B. Artana (ed.). Denpasar, Indonesia, Juli 01, 2006

Wu, Y., Du, P. C., Li, W. G., \& Lu, J. X. (2012). Identification and Molecular Analysis of Pathogenic Yeasts in Droppings of Domestic Pigeons in Beijing, China. Mycopathologia, 174(3), 203-214. https://doi.org/10.1007/s11046-012-9536-9 